\title{
Supporting Information for: Multi-scale individual-based model of microbial and bioconversion dynamics in aerobic granular
}

\section{sludge}

Joao B. Xavier ${ }^{1 *}$, Merle K. de Kreuk², Cristian Picioreanu², Mark C.M. van Loosdrecht ${ }^{2}$

5

1. Biomathematics group, Instituto de Tecnologia Química e Biológica, Universidade Nova de Lisboa, R. Qta Grande 6, 2780 Oeiras, Portugal.

2. Department of Biotechnology, Delft University of Technology. Julianalaan 67, 2628 BC Delft, The Netherlands.

*Corresponding author. Present address: FAS Center for Systems Biology, Harvard University, 7 Divinity Avenue,

Cambridge, MA 02138, USA. E-mail: jxavier@cgr.harvard.edu

\section{Content listing}

- $\quad$ Supporting tables T1, T2, T3, T4 andT5

- Supporting figures F1, F2, F3 and F4

- Legends for supporting simulation movies M1, M2, M3, M4 and M5

- References for the supporting material 
Table T1. Stoichiometric table for the bioconversions considered. Empty table entries denote zero stoichiometric coefficients.

\begin{tabular}{|c|c|c|c|c|c|c|c|c|c|c|c|c|c|c|c|c|c|}
\hline \multirow{2}{*}{ 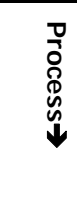 } & Component $\rightarrow$ & $\mathrm{S}_{02}$ & $\mathbf{S}_{\mathrm{AC}}$ & $\mathbf{S}_{\mathrm{NH} 4}$ & $\mathrm{~S}_{\mathrm{NO3}}$ & $\mathrm{S}_{\mathrm{NO2}}$ & $\mathbf{S}_{\mathrm{N} 2}$ & $\mathbf{S}_{\mathbf{P O 4}}$ & $\mathbf{X}_{\mathrm{NH}}$ & $\mathbf{X}_{\mathrm{No}}$ & $\mathbf{X}_{\mathbf{H}}$ & $\mathbf{X}_{\mathrm{PAO}}$ & $\mathbf{X}_{\mathbf{p p}}$ & $\mathbf{X}_{\mathbf{P H A}}$ & $\mathbf{X}_{\mathrm{GLY}}$ & $\mathbf{X}_{1}$ & Rate \\
\hline & & 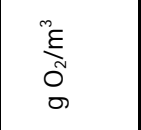 & 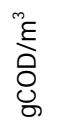 & 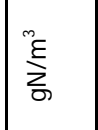 & 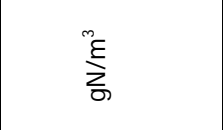 & 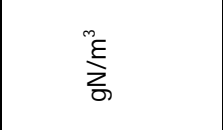 & $\frac{{ }^{m} \xi}{z_{\sigma}}$ & $\frac{\text { m}}{\Delta}$ & 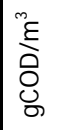 & $\begin{array}{l}\stackrel{n}{E} \\
\stackrel{\partial}{O} \\
\text { Uू }\end{array}$ & $\begin{array}{l}\stackrel{n}{E} \\
\text { Ò } \\
\text { ठ̀ }\end{array}$ & $\frac{\stackrel{n}{\xi}}{\partial}$ & $\frac{{ }^{m}}{\frac{\xi}{\sigma}}$ & $\frac{m^{\xi}}{\partial}$ & 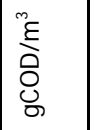 & 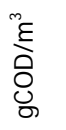 & \\
\hline & Autotrophic & & & & & & & & & & & & & & & & \\
\hline & Nitrification $\left(\mathbf{X}_{\mathrm{NH}}\right)$ & & & & & & & & & & & & & & & & \\
\hline 1 & Growth & $1-3.43 / Y_{\mathrm{NH}}$ & & $-1 / Y_{N H}$ & & $1 / Y_{N H}$ & & & 1 & & & & & & & & $r_{\mathrm{G}, \mathrm{NH}}^{(\mathrm{O} 2)}$ \\
\hline \multirow[t]{2}{*}{2} & Decay & & & & & & & & -1 & & & & & & & 1 & $r_{\mathrm{d}, \mathrm{NH}}^{(\mathrm{O} 2)}$ \\
\hline & Nitrification $\left(\mathbf{X}_{\mathrm{No}}\right)$ & & & & & & & & & & & & & & & & \\
\hline 3 & Growth & $1-1.14 / \mathrm{Y}_{\mathrm{NO}}$ & & & $1 / Y_{\text {NO }}$ & $-1 / Y_{\mathrm{NO}}$ & & & & 1 & & & & & & & $r_{\mathrm{G}, \mathrm{NO}}^{(\mathrm{O} 2)}$ \\
\hline \multirow[t]{3}{*}{4} & Decay & & & & & & & & & -1 & & & & & & 1 & $r_{\mathrm{d}, \mathrm{NO}}^{(\mathrm{O} 2)}$ \\
\hline & Heterotrophic & & & & & & & & & & & & & & & & \\
\hline & Aerobic & & & & & & & & & & & & & & & & \\
\hline \multirow[t]{2}{*}{5} & Growth & $1-1 / Y_{H}$ & $-1 / Y_{H}$ & & & & & & & & 1 & & & & & & $r_{\mathrm{G}, \mathrm{H}}^{(\mathrm{O} 2)}$ \\
\hline & Anaerobic & & & & & & & & & & & & & & & & \\
\hline 6 & Growth & & $-1 / Y_{H}$ & & $\left(1-1 / Y_{H}\right) / 3.43$ & & & & 1 & & & & & & & & $r_{\mathrm{G}, \mathrm{H}}^{(\mathrm{NO})}$ \\
\hline \multirow[t]{3}{*}{7} & Decay & & & & & & & & -1 & & & & & & & 1 & $r_{d, H}$ \\
\hline & PAO & & & & & & & & & & & & & & & & 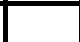 \\
\hline & Anaerobic & & & & & & & & & & & & & & & & \\
\hline \multirow[t]{2}{*}{8} & Storage of acetate & & -1 & & & & & $\mathrm{Y}_{\mathrm{PO} 4}$ & & & & & $-\mathrm{Y}_{\mathrm{PO} 4}$ & $\mathrm{Y}_{\mathrm{PHA}}$ & $1-\mathrm{Y}_{\mathrm{PHA}}$ & & $r_{\mathrm{SA}}^{(\mathrm{AN})}$ \\
\hline & Aerobic & & & & & & & & & & & & & & & & \\
\hline 9 & Consumption of PHA & $1 / \mathrm{Y}_{\mathrm{PHAO}}-1$ & & & & & & & & & & $1 / Y_{\text {PHAO }}$ & & -1 & & & $r_{\text {PHA }}^{(O 2)}$ \\
\hline 10 & Storage of Poly-P & $-1 / Y_{\mathrm{PPO}}$ & & & & & & -1 & & & & $-1 / Y_{\mathrm{PPO}}$ & 1 & & & & $\mathrm{r}_{\mathrm{PP}}^{(\mathrm{OO} 2)}$ \\
\hline \multirow[t]{2}{*}{11} & Glycogen formation & $1-1 / Y_{G L Y O}$ & & & & & & & & & & $-1 / Y_{\mathrm{GLYO}}$ & & & 1 & & $r_{\mathrm{GLY}}^{(\mathrm{O} 2)}$ \\
\hline & Anoxic $\left(\mathrm{NO}_{3}{ }^{-}\right)$ & & & & & & & & & & & & & & & & \\
\hline 12 & Consumption of $\mathrm{PHA}$ & & & & $\left(1 / \mathrm{Y}_{\text {PHANO3-3 }^{-1}}-1\right) / 2.86$ & & $-\left(1 / Y_{\text {PHANO3 }}-1\right) / 2.86$ & & & & & $1 / Y_{\text {PHANO3 }}$ & & -1 & & & $r_{\mathrm{PHA}}^{\text {(NO3) }}$ \\
\hline 13 & Storage of Poly-P & & & & $-1 /\left(\mathrm{Y}_{\mathrm{PPNO}^{3}} * 2.86\right)$ & & $1 /\left(2.86 * Y_{\mathrm{PPNO} 3}\right)$ & -1 & & & & $-1 / Y_{\text {PPNO3 }}$ & 1 & & & & $r_{\mathrm{PP}}^{\text {(NO3) }}$ \\
\hline \multirow[t]{2}{*}{14} & Glycogen formation & & & & $\left(1-1 / Y_{\text {GLYNO3 }}\right) / 2.86$ & & $-\left(1-1 / \mathrm{Y}_{\mathrm{GLYNO}}\right) / 2.86$ & & & & & $-1 / Y_{\text {GLYNO3 }}$ & & & 1 & & $r_{\mathrm{GLY}}^{\text {(NO3) }}$ \\
\hline & Anoxic $\left(\mathrm{NO}_{2}{ }^{-}\right)$ & & & & & & & & & & & & & & & & \\
\hline 15 & Consumption of PHA & & & & & $\left(1 / Y_{\text {PHANO2- }}-1\right) / 1.71$ & $-\left(1 / Y_{\text {PHANO2 }}-1\right) / 1.71$ & & & & & $1 / Y_{\text {PHANO2 }}$ & & -1 & & & $r_{\mathrm{PHA}}^{(\mathrm{NO} 2)}$ \\
\hline 16 & Storage of Poly-P & & & & & $-1 /\left(\mathrm{Y}_{\mathrm{PPNO} 2} * 1.71\right)$ & $1 /(\mathrm{YPPNO} * 1.71)$ & -1 & & & & $-1 / Y_{\mathrm{PPNO} 2}$ & 1 & & & & $r_{\mathrm{PP}}^{(\mathrm{NO} 2)}$ \\
\hline 17 & Glycogen formation & & & & & $\left(1-Y_{\text {GLYNO2 }}\right) / 1.71$ & $-\left(1-1 / Y_{\text {GLYNO2 }}\right) / 1.71$ & & & & & $-1 / Y_{\text {GLYNO2 }}$ & & & 1 & & $r_{\mathrm{GLY}}^{(\mathrm{NO} 2)}$ \\
\hline 18 & Decay & & & & & & & & & & & -1 & & & & 1 & \\
\hline
\end{tabular}


Process

Autotrophic

Nitrification $\left(\mathrm{X}_{\mathrm{NH}}\right)$

1

Growth

Decay

Nitrification ( $\left.\mathbf{X}_{\mathrm{No}}\right)$

3

Growth

Decay

Heterotrophic

Aerobic

5

Growth

\section{Anaerobic}

6 Growth

7 Decay

PAO

Anaerobic

8

Storage of acetate

Aerobic

9

Consumption of PHA

Storage of Poly-P

11 Glycogen formation

\section{Anoxic $\left(\mathrm{NO}_{3}{ }^{-}\right)$}

12

Consumption of PHA

13

14

Storage of Poly- $\mathrm{P}$

Glycogen formation

Anoxic $\left(\mathrm{NO}_{2}{ }^{-}\right)$

15

Consumption of PHA

Storage of Poly-P

17

Glycogen formation

18

Decay
$r_{G, N H}^{\left(O_{2}\right)}=\mu_{N H, \max } \cdot \frac{S_{N H 4}}{S_{N H 4}+K_{N H 4, N H}} \cdot \frac{S_{O 2}}{S_{02}+K_{O 2, N H}} \cdot X_{N H}$

$r_{d, N H}=b_{\text {decay }} \cdot X_{N H}$

$\mathrm{r}_{\mathrm{G}, \mathrm{NO}}^{(02)}=\mu_{\mathrm{NO}, \max } \cdot \frac{\mathrm{S}_{\mathrm{NO} 2}}{\mathrm{~S}_{\mathrm{NO} 2}+\mathrm{K}_{\mathrm{NO} 2, \mathrm{NO}}} \cdot \frac{\mathrm{S}_{\mathrm{O} 2}}{\mathrm{~S}_{\mathrm{O} 2}+\mathrm{K}_{\mathrm{O} 2, \mathrm{NO}}} \cdot \mathrm{X}_{\mathrm{NO}}$

$r_{d, N O}^{(02)}=b_{\text {decay }} \cdot X_{\mathrm{NO}}$

$r_{G, H}^{(02)}=\mu_{H, \text { max }} \cdot \frac{S_{O 2}}{S_{O 2}+K_{O 2, H}} \cdot \frac{S_{A C}}{S_{A C}+K_{A C, H}} \cdot X_{H}$

$r_{\mathrm{G}, \mathrm{H}}^{(\mathrm{NO} 3)}=\mu_{\mathrm{H}, \max } \cdot \eta_{\mathrm{NO} 3} \cdot \frac{\mathrm{S}_{\mathrm{NO} 3}}{\mathrm{~S}_{\mathrm{NO} 3}+\mathrm{K}_{\mathrm{NO} 3, \mathrm{H}}} \cdot \frac{\mathrm{K}_{\mathrm{O} 2, \mathrm{H}}}{\mathrm{S}_{\mathrm{O} 2}+\mathrm{K}_{\mathrm{O} 2, \mathrm{H}}} \cdot \frac{\mathrm{S}_{\mathrm{Ac}}}{\mathrm{S}_{\mathrm{Ac}}+\mathrm{K}_{\mathrm{Ac}, \mathrm{H}}} \cdot \mathrm{X}_{\mathrm{H}}$

$r_{d, H}=b_{\text {decay }} \cdot X_{H}$

$r_{S A}^{(A N)}=q_{s, \max } \cdot \frac{S_{A C}}{S_{A C}+K_{A C, P}} \cdot \frac{f_{P H A, \max }-f_{P H A}}{\left(f_{P H A, \max }-f_{P H A}\right)+K_{P H A, P}} \cdot \frac{f_{P P}}{f_{P P}+0.1} \cdot X_{P A O}$

$r_{P H A}^{(O 2)}=k_{P H A} \cdot \frac{S_{O 2}}{S_{O 2}+K_{O 2, P}} \cdot \frac{f_{P H A}}{f_{P H A}+K_{F P H A, P}} \cdot X_{P A O}$

$r_{P P}^{(02)}=k_{P P} \cdot \frac{S_{02}}{S_{02}+K_{O 2, P}} \cdot \frac{f_{P P, \max }-f_{P P}}{\left(f_{P P, \max }-f_{P P}\right)+K_{P P, P}} \cdot \frac{S_{P O 4}}{S_{P 04}+K_{P 04, P}} \cdot X_{P A O}$

$r_{G L Y}^{(02)}=k_{G L Y} \cdot \frac{S_{02}}{S_{O 2}+K_{O 2, P}} \cdot \frac{f_{P H A}}{f_{P H A}+K_{f P H A, P}} \cdot \frac{f_{G L Y, \max }-f_{G L Y}}{\left(f_{G L Y, \max }-f_{G L Y}\right)+K_{G L Y, P}} \cdot X_{P A O}$

$r_{\mathrm{PHA}}^{(\mathrm{NO} 2)}=\mathrm{K}_{\mathrm{PHA}} \cdot \eta_{\mathrm{NO} 3} \cdot \frac{\mathrm{S}_{\mathrm{NO} 3}}{S_{\mathrm{NO} 3}+\mathrm{K}_{\mathrm{NO} 3, \mathrm{P}}} \cdot \frac{\mathrm{K}_{\mathrm{O} 2, \mathrm{P}}}{S_{02}+\mathrm{K}_{\mathrm{O} 2, \mathrm{P}}} \cdot \frac{\mathrm{f}_{\mathrm{PHA}}}{f_{\mathrm{PHA}}+\mathrm{K}_{\mathrm{FPHA}, \mathrm{P}}} \cdot \mathrm{X}_{\mathrm{PAO}}$

$r_{P P}^{(N O 2)}=k_{P P} \cdot \eta_{N 03} \cdot \frac{S_{N O 3}}{S_{N 03}+K_{N O 3, P}} \cdot \frac{K_{02, P}}{S_{02}+K_{O 2, P}} \cdot \frac{f_{P P, \max }-f_{P P}}{\left(f_{P P, \max }-f_{P P}\right)+K_{P P, P}} \cdot \frac{S_{P 04}}{S_{P 04}+K_{P 04, P}} \cdot X_{P A O}$

$r_{G L Y}^{(N O 2)}=k_{G L Y} \cdot \eta_{N O 3} \cdot \frac{S_{N O 3}}{S_{N O 3}+K_{N O 3, P}} \cdot \frac{K_{02, P}}{S_{02}+K_{O 2, P}} \cdot \frac{f_{P H A}}{f_{P H A}+K_{f P H A, P}} \cdot \frac{f_{G L Y, m a x}-f_{G L Y}}{\left(f_{G L Y, \max }-f_{G L Y}\right)+K_{G L Y, P}} \cdot X_{P A O}$

$r_{\mathrm{PHA}}^{(\mathrm{NO} 3)}=k_{\mathrm{PHA}} \cdot \eta_{\mathrm{NO2}} \cdot \frac{\mathrm{S}_{\mathrm{NO} 2}}{\mathrm{~S}_{\mathrm{NO2}}+\mathrm{K}_{\mathrm{NO} 2, \mathrm{P}}} \cdot \frac{\mathrm{K}_{\mathrm{O} 2, \mathrm{P}}}{\mathrm{S}_{02}+\mathrm{K}_{\mathrm{O} 2, \mathrm{P}}} \cdot \frac{\mathrm{f}_{\mathrm{PHA}}}{f_{\mathrm{PHA}}+\mathrm{K}_{\mathrm{FPHA}, \mathrm{P}}} \cdot \mathrm{X}_{\mathrm{PAO}}$

$r_{P P}^{(N O 3)}=k_{P P} \cdot \eta_{N O 2} \cdot \frac{S_{N O 2}}{S_{N O 2}+K_{N O 2, P}} \cdot \frac{K_{02, P}}{S_{02}+K_{02, P}} \cdot \frac{f_{P P, \max }-f_{P P}}{\left(f_{P P, \max }-f_{P P}\right)+K_{P P, P}} \cdot \frac{S_{P 04}}{S_{P 04}+K_{P 04, P}} \cdot X_{P A O}$

$r_{G L Y}^{(N O 3)}=k_{G L Y} \cdot \eta_{N 02} \cdot \frac{S_{N O 2}}{S_{N 02}+K_{N O 2, P}} \cdot \frac{K_{02, P}}{S_{02}+K_{02, P}} \cdot \frac{f_{P H A}}{f_{P H A}+K_{f P H A, P}} \cdot \frac{f_{G L Y, \max }-f_{G L Y}}{\left(f_{G L Y, m a x}-f_{G L Y}\right)+K_{G L Y, P}} \cdot X_{P A O}$

$r_{\mathrm{d}, \mathrm{PAO}}=\mathrm{b}_{\text {decay }} \cdot \mathrm{X}_{\mathrm{PAO}}$ 
Table T2. Rate expressions for bioconversions.

Table T3. Values for the stoichiometric coefficients in table T1.

\begin{tabular}{|c|c|c|c|c|}
\hline Symbol & Definition & Value & Unit & $\begin{array}{c}\text { Notes/ } \\
\text { Reference }\end{array}$ \\
\hline \multicolumn{5}{|c|}{ Autotrophic organisms: Ammonium oxidizers (XNH) and Nitrite oxidizers (XNO) } \\
\hline $\mathrm{Y}_{\mathrm{NH}}$ & Yield for growth of ammonium oxidizers & 0.15 & $\mathrm{gCOD}-\mathrm{XNH} \cdot \mathrm{gN}^{-1}$ & (1) \\
\hline $\mathrm{Y}_{\mathrm{NO}}$ & Yield for growth of nitrite oxidizers & 0.041 & $g C O D-X N H \cdot g^{-1}$ & (1) \\
\hline \multicolumn{5}{|c|}{ Generic heterotrophic (non-PAO) organisms (XH) } \\
\hline $\mathrm{Y}_{\mathrm{H}}$ & Yield for growth of heterotrophs & 0.47 & gCOD-H·gCOD-Ac ${ }^{-1}$ & (2) \\
\hline \multicolumn{5}{|c|}{ Phosphate Accumulating Organisms ( $\left.\mathbf{X}_{\mathrm{PAO}}\right)$} \\
\hline $\mathrm{Y}_{\mathrm{PO} 4}$ & Anaerobic yield for phosphate release & 0.5 & $\mathrm{gP} \cdot \mathrm{gCOD}-\mathrm{Ac}^{-1}$ & (3) \\
\hline $\mathrm{Y}_{\mathrm{PHA}}$ & Anaerobic yield for PHA formation & 1.5 & gCOD-PHA.gCOD-Ac ${ }^{-1}$ & (3) \\
\hline $\mathrm{Y}_{\text {PHAO }}$ & Aerobic yield for PHA degradation & 1.39 & gCOD-PHA.gCOD-XPAO ${ }^{-1}$ & (4) \\
\hline$Y_{P P O}$ & Aerobic yield for Poly-P formation & 4.42 & $g P \cdot g C O D-X P A O^{-1}$ & (4) \\
\hline$Y_{G L Y O}$ & Aerobic yield for glycogen formation & 1.11 & gCOD-Gly·gCOD-XPAO-1 & (4) \\
\hline Y PHANO3 & Anoxic yield for PHA degradation on nitrate & 1.7 & gCOD-PHA.gCOD-XPAO-1 & (4) \\
\hline $\mathrm{YPPNO3}_{3}$ & Anoxic yield for Poly-P formation on nitrate & 3.02 & $g P \cdot g C O D-X P A O^{-1}$ & (4) \\
\hline $\mathrm{Y}_{\mathrm{GLYNO3}}$ & Anoxic yield for glycogen formation on nitrate & 1.18 & gCOD-Gly·gCOD-XPAO-1 & (4) \\
\hline $\mathrm{Y}_{\text {PHANO2 }}$ & Anoxic yield for PHA degradation on nitrite & 1.7 & gCODPHA.gCOD-XPAO-1 & (4) \\
\hline $\mathrm{Y}_{\mathrm{PPNO2}}$ & Anoxic yield for Poly-P formation on nitrite & 3.02 & $g P \cdot g C O D-X P A O^{-1}$ & (4) \\
\hline$Y_{\text {GLYNO2 }}$ & Anoxic yield for glycogen formation on nitrite & 1.18 & gCOD-Gly·gCOD-XPAO-1 & (4) \\
\hline
\end{tabular}


Table T4. Values for the kinetic parameters in table T2.

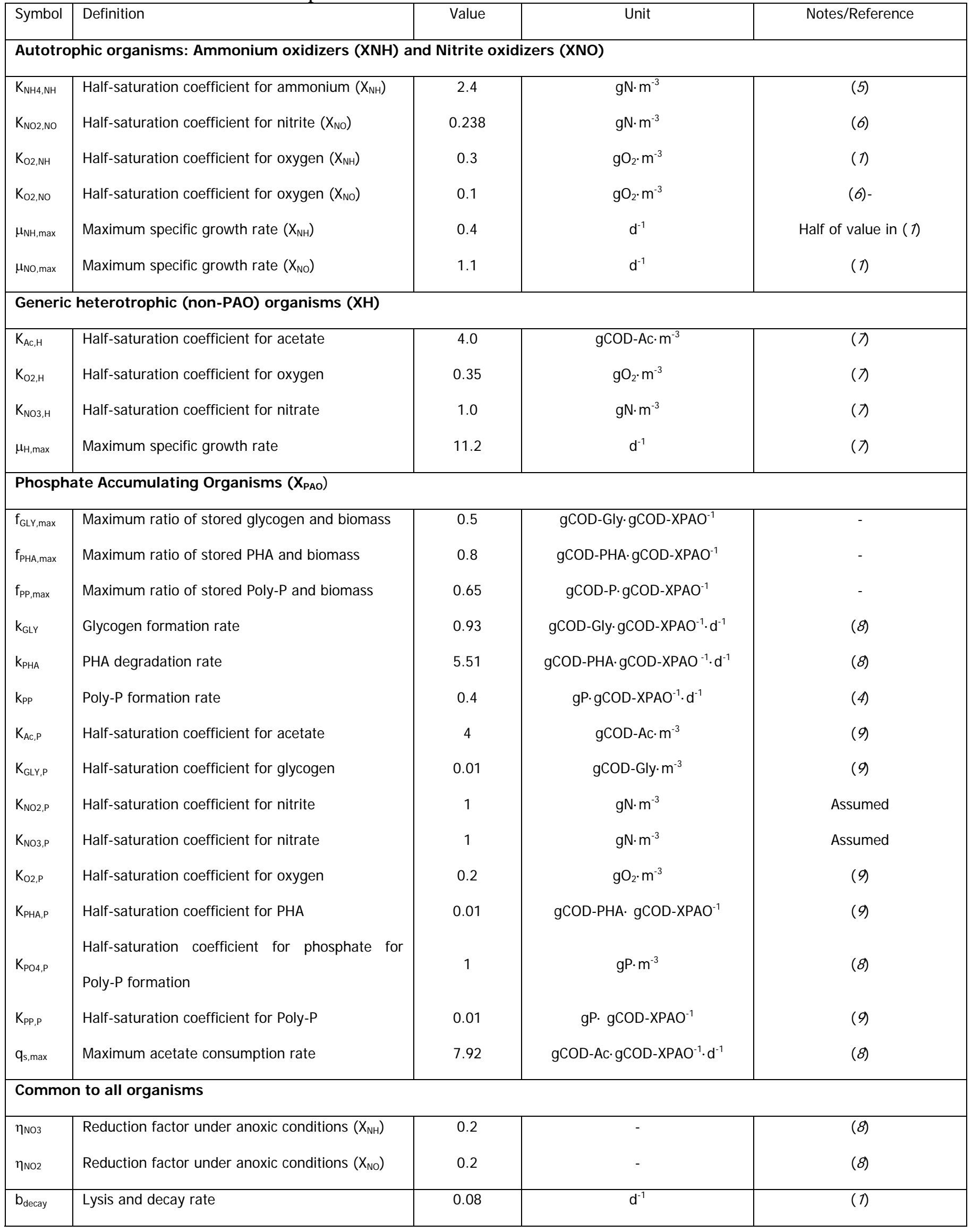


Table T5. Physical parameters ${ }^{1}$ and operation conditions used in the simulations.

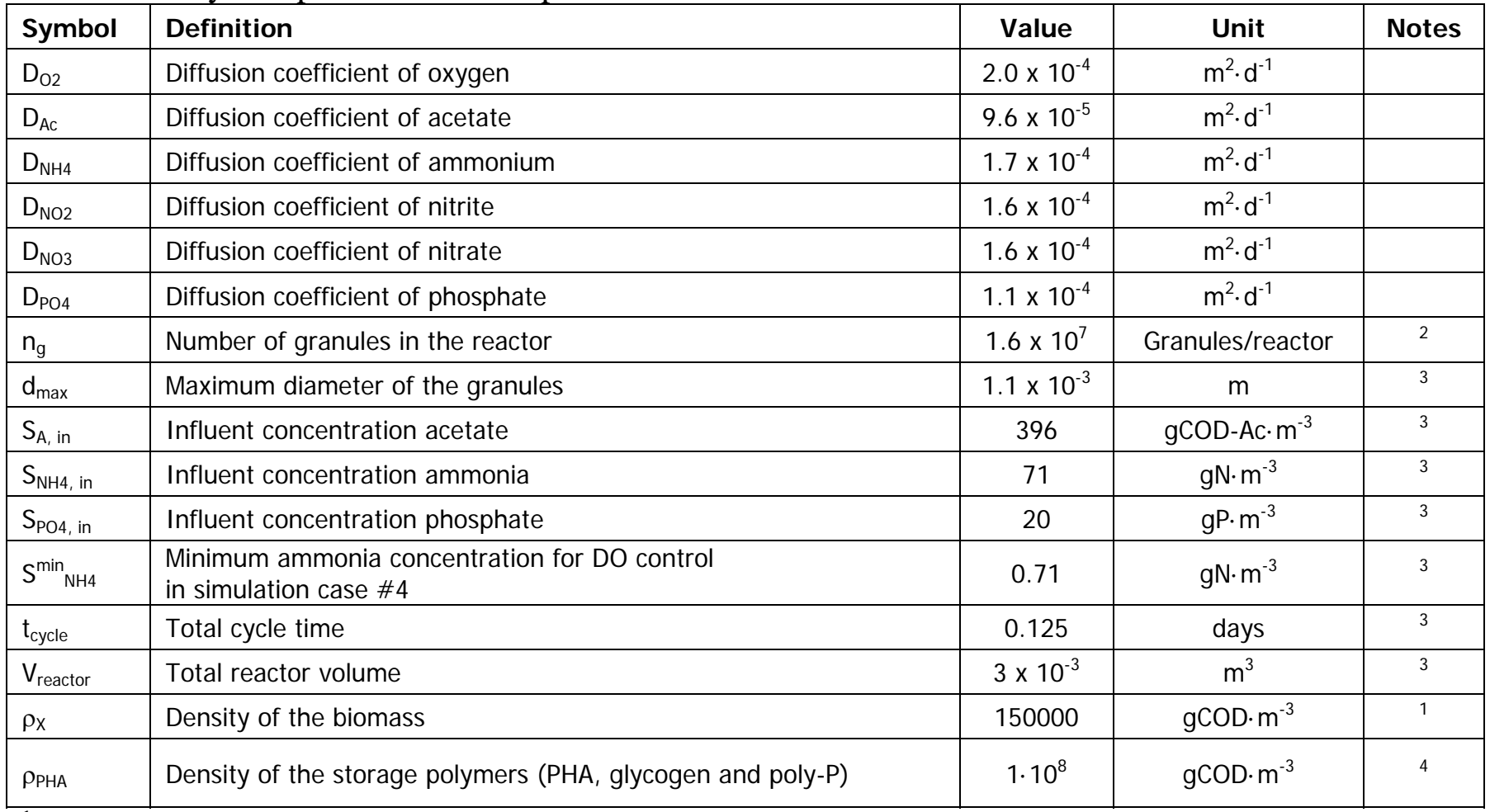

${ }^{1}$ For detailed explanation of model construction and signification of model parameters see $(5,10)$

${ }^{2}$ Typical values to produce total amount of biomass the same as in laboratory scale GSBR

${ }^{3}$ Typical values used in the operation of laboratory scale GSBR

${ }^{4} \mathrm{~A}$ high value of $\rho_{\mathrm{PHA}}$ was assumed to make the volume of storage particulate components negligible compared with the active biomass. 

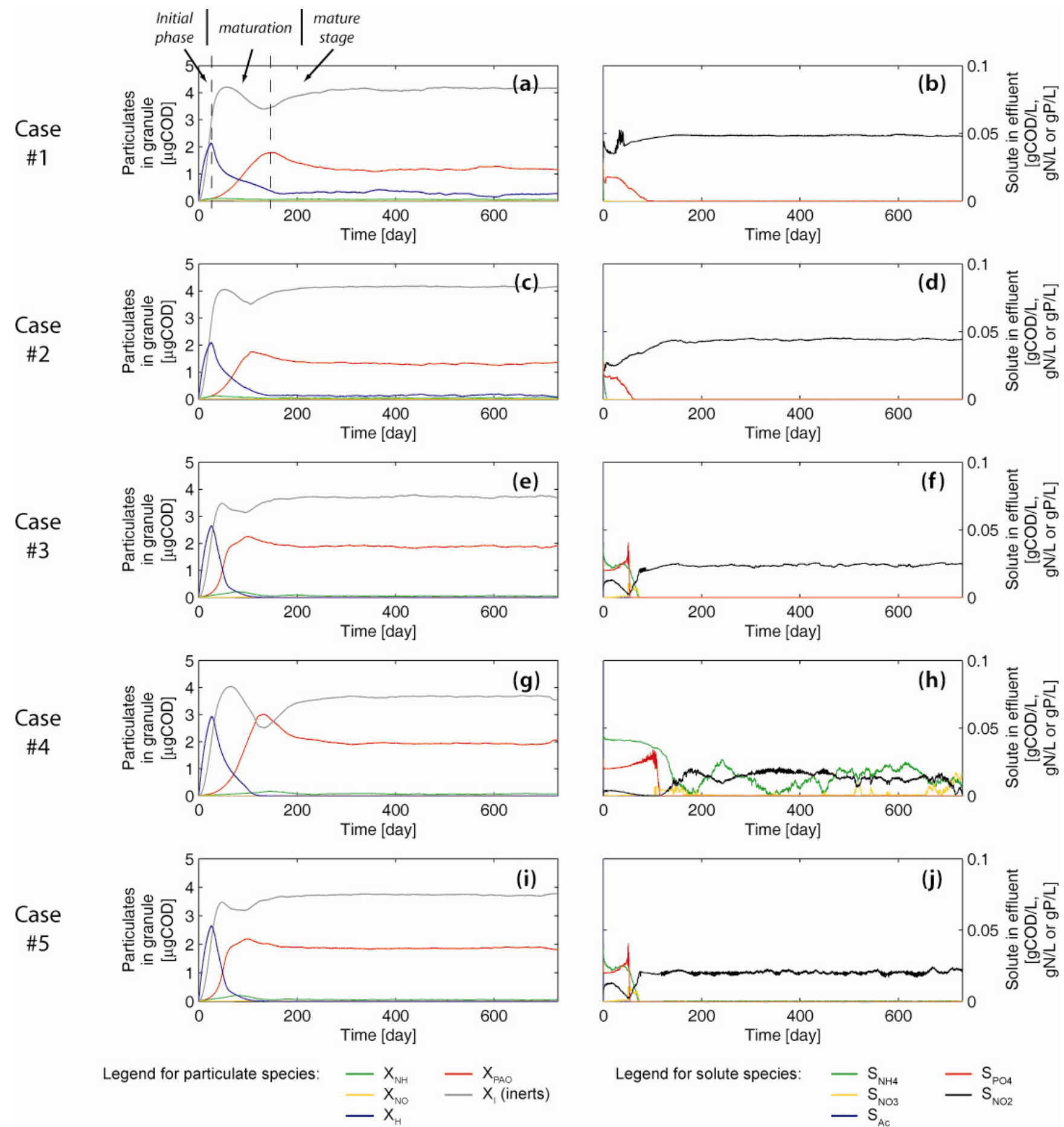

Figure F1. The dynamics of mass of the bacterial groups and inerts in the granule (panes a, c, e, g and i) and solute concentrations in the reactor effluent (panes b, d, f, h and j) for the entire two years of simulation of the 5 simulations carried out. 

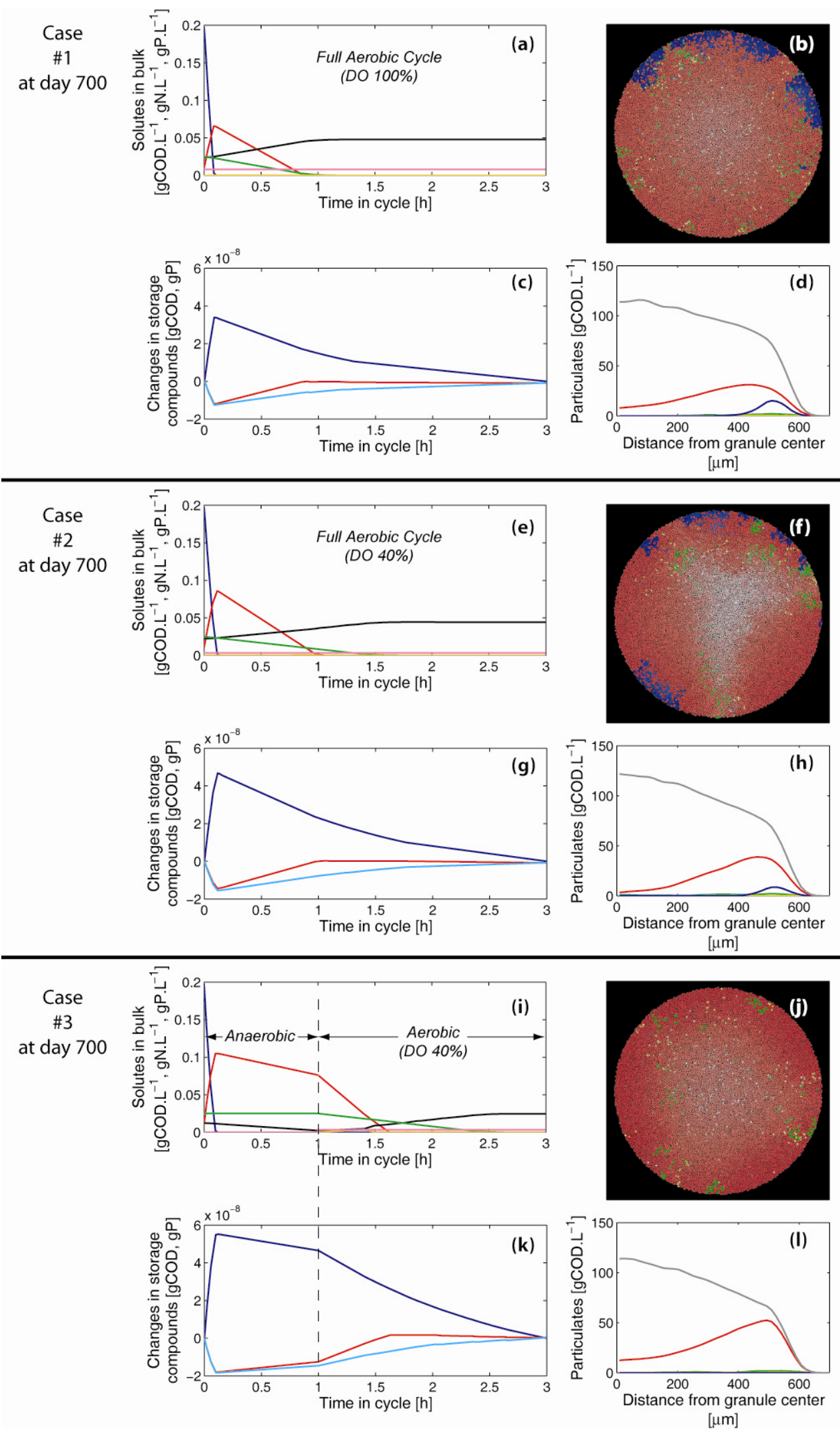

Figure F2 (continues on next page, see below for legend) 

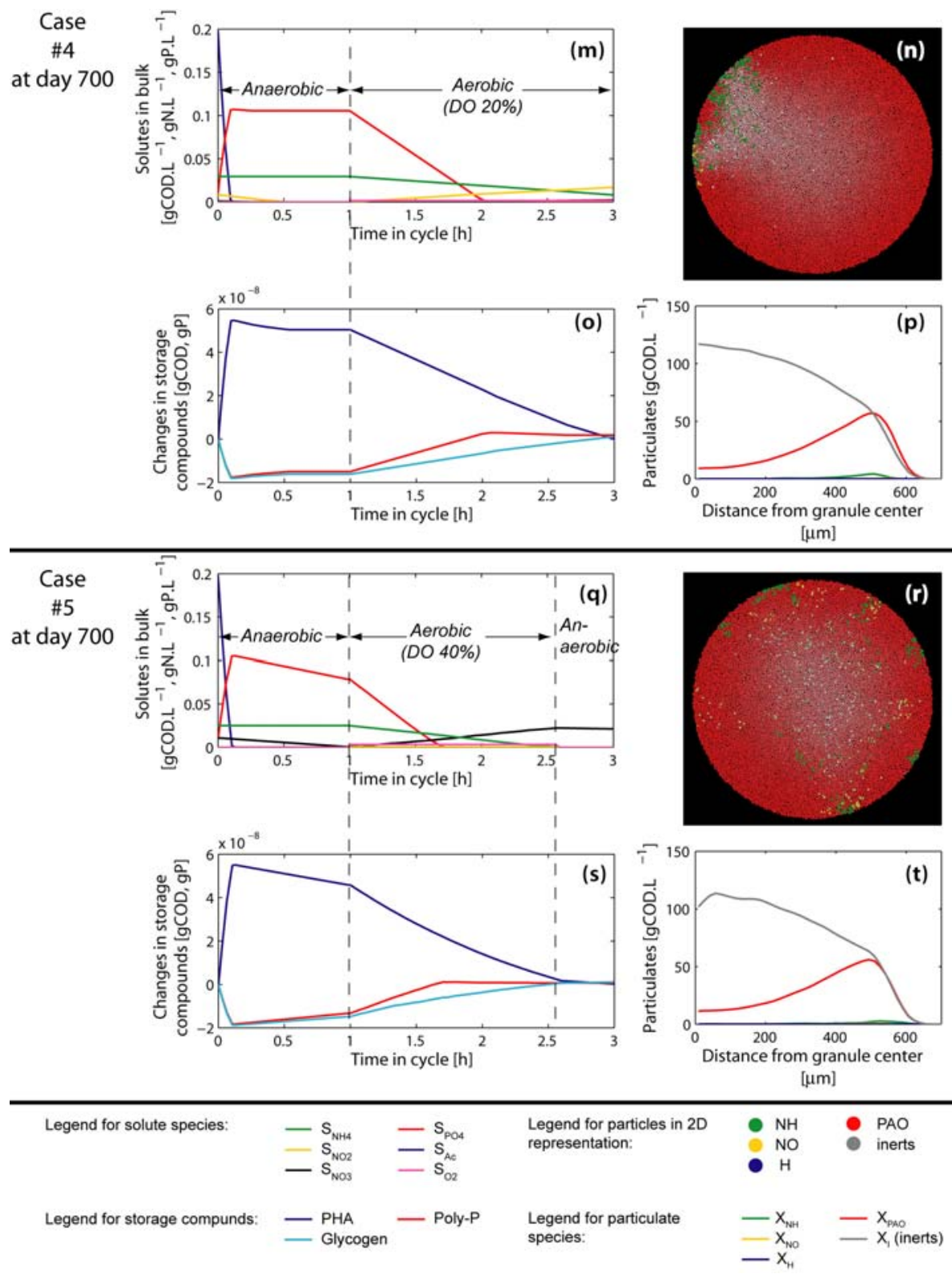

Figure F2. Results from a three-hour cycle representative of the mature state (at day 700) for each of the five cases simulated here. Panes a, e, i, m and q (top left panes) represent bulk concentrations of all solutes. Panes b, f, j, n and r (top right panes) show the 2-d distribution of bacterial groups (ammonia oxidizers $\mathrm{NH}$, nitrite oxidizers $\mathrm{NO}$, heterotrophs $\mathrm{H}$ and phosphate accumulating organisms $\mathrm{PAO}$ ) and inert material in the granule. Panes c, g, k, o and s (bottom left panes) show the absolute changes in mass of internal storage compounds (PHA, Poly-P and glycogen) in the granule during the cycle. Panes $\mathrm{d}, \mathrm{h}, \mathrm{l}, \mathrm{p}$ and t (bottom right panes) show the average radial distribution of bacterial groups and inerts, derived from the 2-d distribution. 


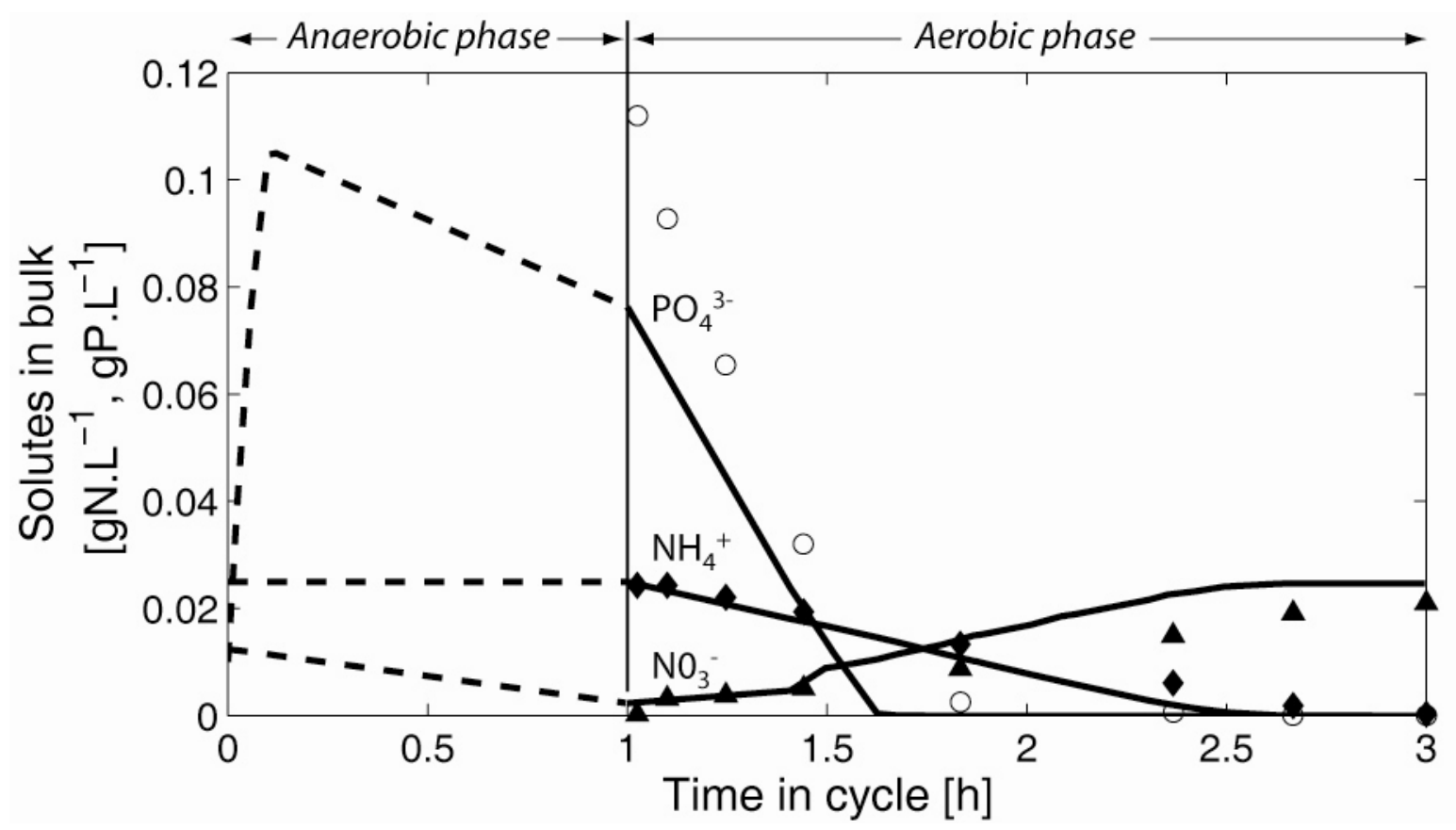

Figure F3. Comparison between simulation data (lines) and experimental data (symbols) obtained from the operation of a lab scale GSBR. The plot shows $\mathrm{PO}_{4}{ }^{3-}(\mathrm{O}), \mathrm{NH}_{4}{ }^{+}(\diamond)$ and $\mathrm{NO}_{3}{ }^{-}(\boldsymbol{\Delta})$ bulk concentrations during the aerobic phase of one cycle operation in the conditions defined for simulations from case \#3 (1 h anaerobic phase followed by $2 \mathrm{~h}$ aerobic phase at $40 \% \mathrm{DO}$, data from (11)). 

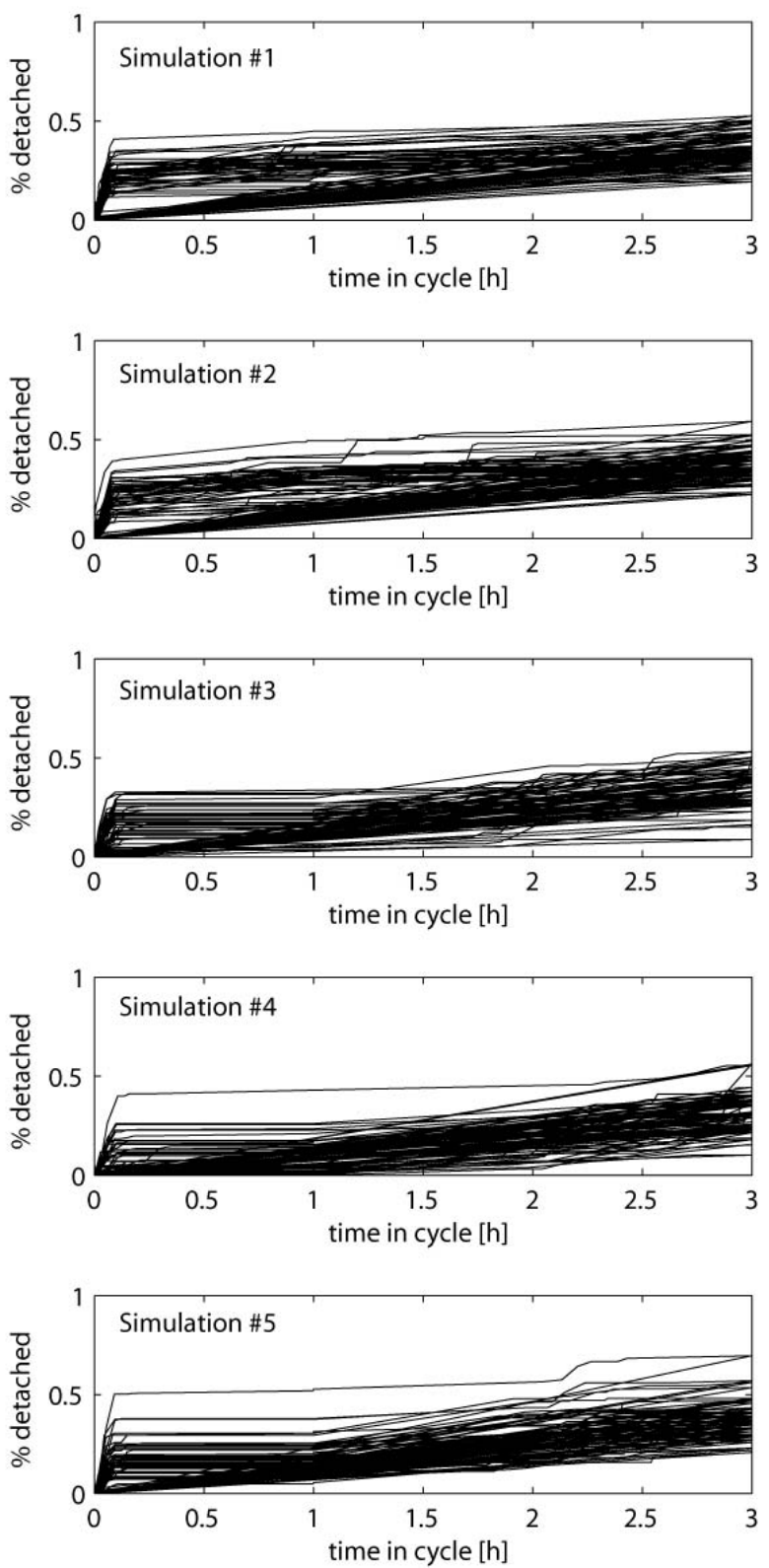

Figure F4. The percentage of detached biomass that accumulates before it is removed at the end of each 3 h cycle. Panels show results from multiple 3-h cycles for the 5 simulations carried out. \% detached is calculated by the percentage of biomass detached over total biomass in the reactor (granule and detached). The percentage never accumulates to significantly high values (is always lower than $1 \%$ ) because the duration of each cycle is very short when compared to the time-scale of growth and detachment. This supports the usual assumption (11-13) that bioconversions by detached biomass may be neglected in the aerobic granular sludge process. 


\section{Supporting movie files}

The movie files are animations showing the dynamics of granule growth and maturation in 2-d together with the bulk concentration dynamics for an entire 3h cycle of operation. The files supplied are the following:

file sim1_low.mov - Movie from case \#1

file sim2_low.mov - Movie from case \#2

file sim3_low.mov - Movie from case \#3

file sim4_low.mov - Movie from case \#4

file sim5_low.mov - Movie from case \#5

Higher resolution movie files may be obtained from our website at http://www.itqb.unl.pt:1111/ jxavier/gsbr/ 


\section{References for supporting material}

(1) Wiesmann, U., Biological nitrogen removal from wastewater. Advances in Biochemical Engineering/Biotechnology 1994, 51, 113-154.

(2) Xavier, J. B.; Picioreanu, C.; Van Loosdrecht, M. C. M., A modelling study of the activity and structure of biofilms in biological reactors. Biofilms 2004, 1, (4), 377-391.

(3) Smolders, G. J. F.; Vandermeij, J.; Vanloosdrecht, M. C. M.; Heijnen, J. J., Model Of The Anaerobic Metabolism Of The Biological Phosphorus Removal Process - Stoichiometry And Ph Influence. Biotechnology And Bioengineering 1994, 43, (6), 461-470.

(4) Murnleitner, E.; Kuba, T.; vanLoosdrecht, M. C. M.; Heijnen, J. J., An integrated metabolic model for the aerobic and denitrifying biological phosphorus removal. Biotechnology And Bioengineering 1997, 54, (5), 434-450.

(5) Picioreanu, C.; Kreft, J. U.; Van Loosdrecht, M. C. M., Particle-based multidimensional multispecies model. Appl Environ Microbiol 2004, 70, (5), 3024-3040.

(6) Wijffels, R. H.; Tramper, J., Nitrification By Immobilized Cells. Enzyme And Microbial Technology 1995, 17, (6), 482-492.

(7) Xavier, J. B.; Picioreanu, C.; van Loosdrecht, M. C. M., A general description of detachment for multidimensional modelling of biofilms. Biotechnol Bioeng 2005, 91, (6), 651-69.

(8) Hao, X.; Van Loosdrecht, M. C. M.; Meijer, S. C.; Qian, Y., Model-based evaluation of two BNR processes--UCT and A2N. Water Res 2001, 35, (12), 2851-60.

(9) Gujer, W.; Henz, M.; Takahashi, M.; Van Loosdrecht, M. C. M., Activated sludge model No. 3. Wat Sci Technol 1999, 39, (1), 183-193.

(10) Xavier, J. B.; Picioreanu, C.; van Loosdrecht, M. C. M., A framework for multidimensional modelling of activity and structure of multispecies biofilms. Environ Microbiol 2005, 7, (8), 1085-103.

(11) de Kreuk, M. K.; Picioreanu, C.; Hosseini, M.; Xavier, J. B.; Loosdrecht, M. C. M. v., Kinetic model of a granular sludge SBR - influences on nutrient removal. Biotechnology and Bioengineering 2007, 97, (4), 801-815.

(12) Beun, J. J.; van Loosdrecht, M. C. M.; Heijnen, J. J., Aerobic granulation in a sequencing batch airlift reactor. Water Res 2002, 36, (3), 702-12.

(13) Beun, J. J.; Heijnen, J. J.; van Loosdrecht, M. C. M., N-removal in a granular sludge sequencing batch airlift reactor. Biotechnol Bioeng 2001, 75, (1), 82-92. 